\title{
Quality and Method of Management of Drinking Water in Rural Areas in Benin: Case of Artesian Drills of Dogbo Ahomey in the Borough of Tota, Municipality of Dogbo
}

\author{
Armelle Sabine Yélignan Hounkpatin ${ }^{1,2 *}$, Victorien Tamégnon Dougnon ${ }^{3}$, \\ Hounsa Jules², Eliasse Kpognon ${ }^{4}$, Rock Christian Johnson ${ }^{2}$
}

${ }^{1}$ Plurildisciplinary Research Laboratory for Technical Education (PRLaTE)/ENSET Lokossa-UNSTIM, Benin

${ }^{2}$ Lobratoiry of Hygiene Sanitation, Toxicology and Environment Health (HECOTES), Training Center of Interfacultary and Environment Research for Sustainable Development (CIFRED), University of Abomey-Caalavi, Cotnou, Benin

${ }^{3}$ Research Unit in Applied Microbiology and Pharmacology of Natural Substances, Research Laboratory in Applied Biology, Polytechnic School of Abomey-Calavi, University of Abomey-Calavi, Cotonou, Benin

${ }^{4}$ Water and Food Quality Control Laboratory (LCQEA), Departmental Directorate of Health (DDS) of the Littoral, Benin

Email: ^harmelle2011@gmail.com

How to cite this paper: Hounkpatin, A.S.Y., Dougnon, V.T., Jules, H., Kpognon, E. and Johnson, R.C. (2021) Quality and Method of Management of Drinking Water in Rural Areas in Benin: Case of Artesian Drills of Dogbo Ahomey in the Borough of Tota, Municipality of Dogbo. Journal of Water Resource and Protection, 13, 823-834. https://doi.org/10.4236/jwarp.2021.1311044

Received: October 1, 2021

Accepted: November 1, 2021

Published: November 4, 2021

Copyright () 2021 by author(s) and Scientific Research Publishing Inc. This work is licensed under the Creative Commons Attribution International License (CC BY 4.0).

http://creativecommons.org/licenses/by/4.0/ (c) (i) Open Access

\begin{abstract}
The objective of this study is to assess the quality of the artesian borehole water consumed by the population of the village of Dogbo Ahomey in order to prevent pathologies on the populations. Methodology and Results: The household surveys were supplemented by a campaign to analyze the water samples in the laboratory. The samples were analyzed according to the standardized methods of the American Public Health Association (APHAAWWA-WPCF, 1994). A total of twenty (20) physico-chemical parameters and four (04) microbiological parameters were used to assess the quality of the different water samples. The results of the physico-chemical analysis showed that the water samples studied present values that are below the standards recommended by the $\mathrm{WHO}$ and by the Beninese standards for the quality of drinking water (Standards, 2001). From a microbiological analysis point of view, of the four samples studied, two show strong pollution by germs. This could be a significant health risk for households who take water from these sources to meet their needs.
\end{abstract}

\section{Keywords}

Drinking Water, Drilling, Microbiology, Rural Area, Dogbo Ahomey 


\section{Introduction}

Access to drinking water is a major issue in developing countries [1]. Unfortunately, many people in rural areas do not yet have access to a drinking water service as desired by the SDGs [2]. With regard to global statistics, in 2019 an estimate of 2.2 billion people, or $29 \%$ of the world population, do not have access to safely managed domestic drinking water supply services, of which 144 million people use only untreated surface water sources [3] [4]. A study carried out on the quality of the water consumed in the commune of Adjohoun in Benin, shows that the populations of the villages do not have access to water from the SONEB [5]. Most of the population consumes spring water without prior treatment. Access to safe drinking water is a prerequisite for health, an essential human right and a key component of effective health protection policies [6] [7]. Despite all the legal and institutional arrangements in the water sector, 3.5 billion [4] people drink dirty or questionable water every day. Today, 2.1 billion [8] [9] human beings do not have safe access to safe drinking water. The dramatic consequence is that unsanitary water kills 2.6 million [8] [10] people each year, most of them children, due to water-borne diseases such as diarrhea and cholera. No other determining environmental factor has effects as profound, as fragile and as dehumanizing as water. According to statistics, 2 out of 5 Beninese have access to drinking water in rural areas, with strong disparities between departments. In urban areas, the access rate is $76 \%$ [3] [11]. To consume water without danger, a control and management policy must take into account the characteristics of water, a precious molecule [12] [13]. The water must therefore undergo various analyzes that will define its quality, for human consumption, in order to avoid the risks of water-borne diseases for consumers [14]. This study is concerned with the study of the physico-chemical and microbiological quality of water from artesian boreholes in the village of Dogbo Ahomey in the district of Tota, municipality of Dogbo in Benin.

\section{Study Framework and Method}

\subsection{Study Framework}

Our study took place in the village of Dogbo Ahomey in the district of Tota, municipality of Dogbo (Figure 1). The Municipality of Dogbo is located in the southwest of the Republic of Benin and, more precisely, in the south of the Couffo department. It is bounded to the South by the Municipalities of Lokossa and Bopa, to the North by the Municipalities of Lalo, Toviklin and Djakotomey, to the East by the Municipalities of Lalo and Toffo and to the West by the Republic of Togo. It covers an area of $475 \mathrm{~km}^{2}$ with an average altitude of 80 meters [15]. Demographically, the total population of the municipality of Dogbo is 90,583 inhabitants [15], including 36,099 in urban areas concentrated in Tota. The city of Tota is the capital of the Municipality. 


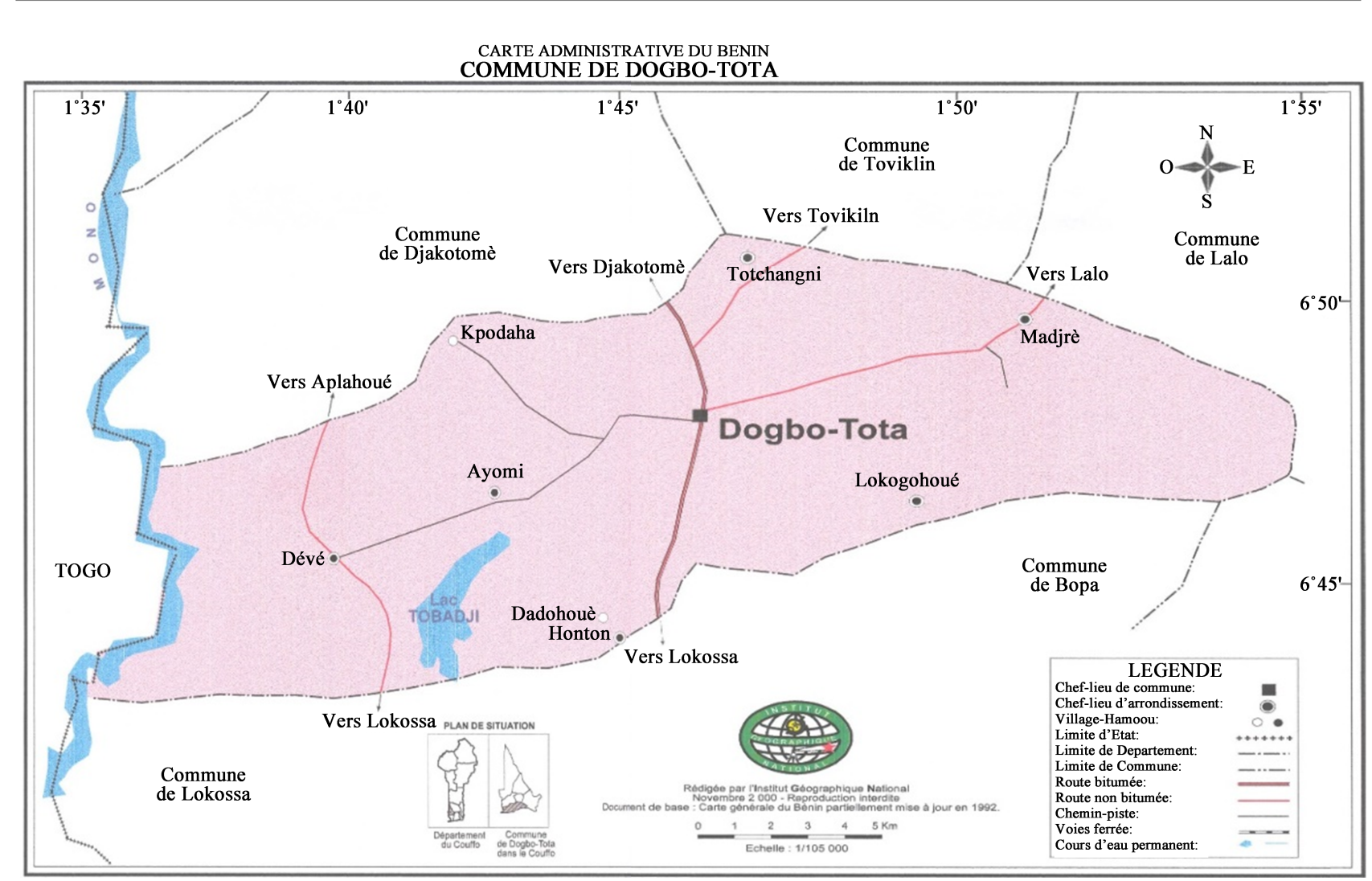

Source: National Geographic Institute, Number 2000.

Figure 1. Geographic map of the study area and environment.

\subsection{Study Methods}

\subsubsection{Type of Study}

This is a descriptive cross-sectional study with an analytical aim carried out on the physico-chemical and microbiological quality of artesian borehole water used in households in the village of Dogbo Ahomey in the district of Tota, municipality of Dogbo.

\subsubsection{Sampling}

The water samples analyzed were taken from three (03) identified artesian boreholes and from a household tap in the study area. In total, 12 samples were taken from the four (04) water sources at the rate of one sample for physicochemical analysis and two for microbiological analysis. The geographic coordinates of the sampling points are presented in the Table 1 below.

\subsubsection{Taking Water Samples}

The water samples are taken in sterilized plastic bottles for the analysis of physico-chemical parameters and in $500 \mathrm{ml}$ WHIRL PAK sachets for microbiological analysis. The water samples are stored in cooler containing accumulators and then taken to the laboratory. The analyses are carried out at the Food and Water Quality Control Laboratory (LCQEA) located within the Departmental Directorate of Health (DDS) of the Littoral in Placodji (Republic of Benin). 
Table 1. Geographical coordinates of sampling points.

\begin{tabular}{ccc}
\hline & \multicolumn{2}{c}{ Geographical coordinates } \\
\cline { 2 - 3 } Sampling points & $\mathrm{X}$ & $\mathrm{Y}$ \\
\hline Ahomey drilling & 6.797422 & 1.746227 \\
Yobohoué drilling & 6.803588 & 1.744913 \\
Tétéhoué drilling & 6.806810 & 1.746162 \\
\hline
\end{tabular}

Source: Fieldwork, 2020.

\section{Analysis of Samples}

\subsection{Physico-Chemical Parameters}

The physico-chemical analyzes concern the following parameters: temperature, hydrogen potential, electrical conductivity, total dissolved solids, salinity, turbidity, color, sulfates, ortho-phosphates, nitrites, nitrates, ammonium, chlorides, fluorides, manganese, calcium, magnesium, total hardness, bicarbonates and total iron. The physico-chemical analyzes were carried out according to the assay methods such as volumetry and spectrophotometry. The hydrogen potential $(\mathrm{pH})$ by the potentiometric method with the $\mathrm{pH}$ meter, the color by spectrophotometer and the temperature, electrical conductivity, TDS, salinity, turbidity are determined by the electrometric method. Nitrates $\left(\mathrm{NO}_{3}^{-}\right)$, nitrites $\left(\mathrm{NO}_{2}^{-}\right)$, ammonium $\left(\mathrm{NH}_{4}^{+}\right)$, iron $(\mathrm{Fe})$, fluorides $\left(\mathrm{F}^{-}\right)$, chlorides $\left(\mathrm{CL}^{-}\right)$ortophosphates $\mathrm{PO}_{4}^{3-}$ were determined by colorimetric assay using of a spectrophotometer (DR/2800). The reagents used were $\mathrm{HACH}$ kits. The content of sulfate ions $\left(\mathrm{SO}_{4}^{2-}\right)$, calcium $\left(\mathrm{Ca}^{2+}\right)$, magnesium $\left(\mathrm{Mg}^{2+}\right)$ and hardness $(\mathrm{TH})$ is determined by titration with Ethylene-Diamine Tetra Acetic acid (EDTA). Finally, the bicarbonate $\left(\mathrm{HCO}_{3}^{-}\right)$ content is determined by titration using hydrochloric acid. Table 1 shows the standards for the physicochemical parameters of the quality of drinking water.

\subsection{Microbiological Parameters}

The microbiological parameters were analyzed in the laboratory according to the Rodier analysis standard (1978 and 2009). The methods of detection and enumeration of the germs used are those of reference retained by the standard. This involves the preparation of the room, the preparation of culture media and working materials, seeding, incubation and reading. Table 2 shows the desired microbiological parameters.

\section{Results}

\subsection{Physico-Chemical Parameters}

The result of the physico-chemical parameters obtained is below the recommended standards. It emerges from the analysis of Table 3 that only the temperature, the potential of Hydrogen and Ammonium have a high significant value. 
Table 2. Desired microbiological parameters.

\begin{tabular}{ccc}
\hline PARAMETRES & TECHNICAL USED & STANDARDS \\
\hline $\begin{array}{c}\text { Common germs per } 1 \mathrm{~mL} \text { of CFU } \\
\text { Suspected Coliforms }(\mathrm{CFU} / 100 \mathrm{~mL})\end{array}$ & NFT 90401. PCA medium. $\left(24-48 \mathrm{~h}\right.$ at $\left.37^{\circ} \mathrm{C}\right)$ & 50 \\
Thermotolerant coliforms & NFV-08-05. Rapid-E Coli medium $\left(24 \mathrm{~h}\right.$ at $\left.37^{\circ} \mathrm{C}\right)$ & 0 \\
$(\mathrm{CFU} / 100 \mathrm{~mL})$ & & 0 \\
Escherichia coli $(\mathrm{CFU} / 100 \mathrm{~mL})$ & NFV-08-05. Rapid-E Coli medium $\left(24 \mathrm{~h}\right.$ at $\left.44^{\circ} \mathrm{C}\right)$ & 0 \\
\hline
\end{tabular}

Source: Laboratory work, 2020.

Table 3. Results of the physico-chemical parameters of the four water samples.

\begin{tabular}{|c|c|c|c|c|c|}
\hline Settings & Standards & Ahomey & Yobohoué & Tétéhoué & SONEB \\
\hline Temperature & $\sim 25^{\circ} \mathrm{C}$ & 30.2 & 30.1 & 30.1 & 30.2 \\
\hline Hydrogen potential & $6.5-8.5 \mathrm{pH}$ & 5.1 & 5.2 & 5.6 & 5.1 \\
\hline Electrical conductivity & $2000 \mathrm{CE}$ & 65 & 54 & 60 & 76 \\
\hline Total dissolved solids & - & 32 & 27 & 30 & 38 \\
\hline Salinity & - & 0.01 & 0.01 & 0.016 & 0.01 \\
\hline Turbidity & - & 0.65 & 0.25 & 0.19 & 0.2 \\
\hline Color & 15 & $<0.01$ & $<0.01$ & $<0.01$ & $<0.01$ \\
\hline Sulphates & 400 & 0.1 & 1.4 & 0.5 & 0.3 \\
\hline Ortho-phosphates & 5 & 0.2 & 0.14 & 0.23 & 0.2 \\
\hline Nitrites & 0.1 & 0.009 & 0.009 & 0.008 & 0.007 \\
\hline Nitrates & 45 & 15.5 & 10.6 & 11.7 & 15.3 \\
\hline Ammonium & 0.5 & 0.15 & 0.04 & 0.52 & 0.05 \\
\hline Chlorides & 250 & 7 & 7 & 9 & 7 \\
\hline Fluorides & 1.5 & $<0.01$ & $<0.01$ & 0.03 & $<0.01$ \\
\hline Manganese & 0.05 & 0.004 & $<0.001$ & 0.002 & 0.005 \\
\hline Calcium & 100 & 3.2 & 3.2 & 3.2 & 7.6 \\
\hline Magnesium & 50 & 1.69 & 1.45 & 1.45 & 1.45 \\
\hline Total hardness & 400 & 15 & 14 & 14 & 25 \\
\hline Bicarbonates & - & 8.54 & 8.54 & 8.54 & 8.54 \\
\hline Iron & 0.3 & 0.13 & 0.12 & 0.15 & 0.13 \\
\hline
\end{tabular}

Source: Laboratory work, 2020.

- The temperature

The temperature of the water is an important factor in organic production. Table 2 shows variations in temperature from one source to another. The minimum value is 30.1 and the maximum value is 30.2 . These values are above the recommended standards. This could be explained by the influence of ambient heat on the water withdrawn and also by the geothermal gradient of the area. 
- The potential of Hydrogen ( $\mathrm{pH})$

The potential of Hydrogen $(\mathrm{pH})$, expresses the concentration in acidity or basicity of water. A pH below 7 indicates the water is acidic and above 7 indicates the water is alkaline. Table 2 indicates that the minimum $\mathrm{pH}$ value is 5.1 and the maximum value is 5.6., which testifies to a slight acidity in the middle.

- Ammonium

Ammonium in water usually reflects an incomplete degradation process of organic matter. It is an excellent indicator of water pollution by organic waste from agricultural, domestic or industrial sources. The recommended Ammonium standard is 0.15 . From Table 2 it can be seen that the minimum value of Ammonium is 0.04 and the maximum value is 0.52 . This high rate of the Tétéhoué water sample indicates the pollution of this water source. The results of the physicochemical analysis presented in this study may be considered admissible and have no effect on the physicochemical quality of the water from the various water sources.

\subsection{Microbiological Parameters}

\subsubsection{Ahomey Drilling}

Figure 2 shows the level of pollution of the Ahomey water sample by common germs.

Figure 2 indicates that the Ahomey water sample has a pollution level of 10 $\mathrm{mL} / \mathrm{CFU}$ of common germs. This value is well below the standard for the quality of drinking water allowed. On the other hand, the other parameters (Presumed Coliforms, Thermotolerant Coliforms, Escherichia coli) have no value. Analysis of this figure shows that Ahomey's sample meets Beninese and WHO standards for the microbiological quality of drinking water.

\subsubsection{Yobohoué Drilling}

Figure 3 shows the level of pollution of the Yobohoué water sample by germs.

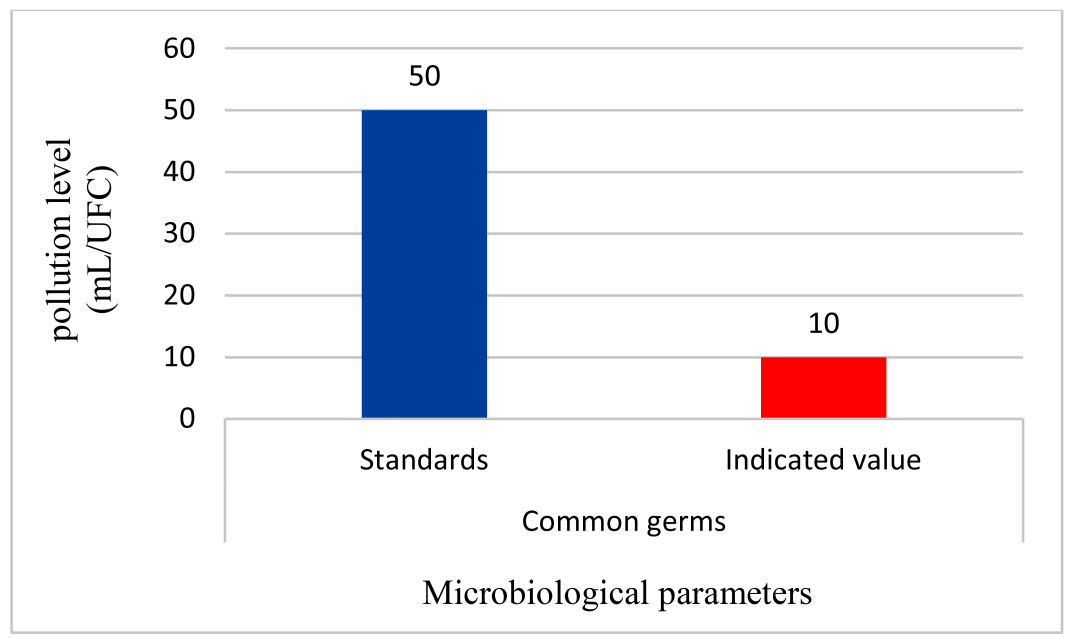

Source: Laboratory work, 2020.

Figure 2. Pollution level of Ahomey's water sample by common germs. 
Figure 3 indicates that the Yobohoue water sample has a pollution level of 54 $\mathrm{mL} / \mathrm{CFU}$ from common germs, $6 \mathrm{~mL} / \mathrm{CFU}$ from suspected coliforms and 54 $\mathrm{mL} / \mathrm{CFU}$ from thermotolerant coliforms. These values are above the standard for the quality of drinking water allowed. On the other hand, Escherichia coli is of no value. Analysis of this figure shows that Yobohoué's drinking water source does not meet Beninese and WHO standards for the microbiological quality of drinking water.

\subsubsection{Tétéhoué Drilling}

Figure 4 shows the level of contamination of the Tétéhoué water sample by germs.

Figure 4 indicates that the water sample from Tétéhoué has a pollution level of $42 \mathrm{~mL} / \mathrm{CFU}$ from common germs, $5 \mathrm{~mL} / \mathrm{CFU}$ from suspected coliforms. These values are above the accepted drinking water quality standards. On the other

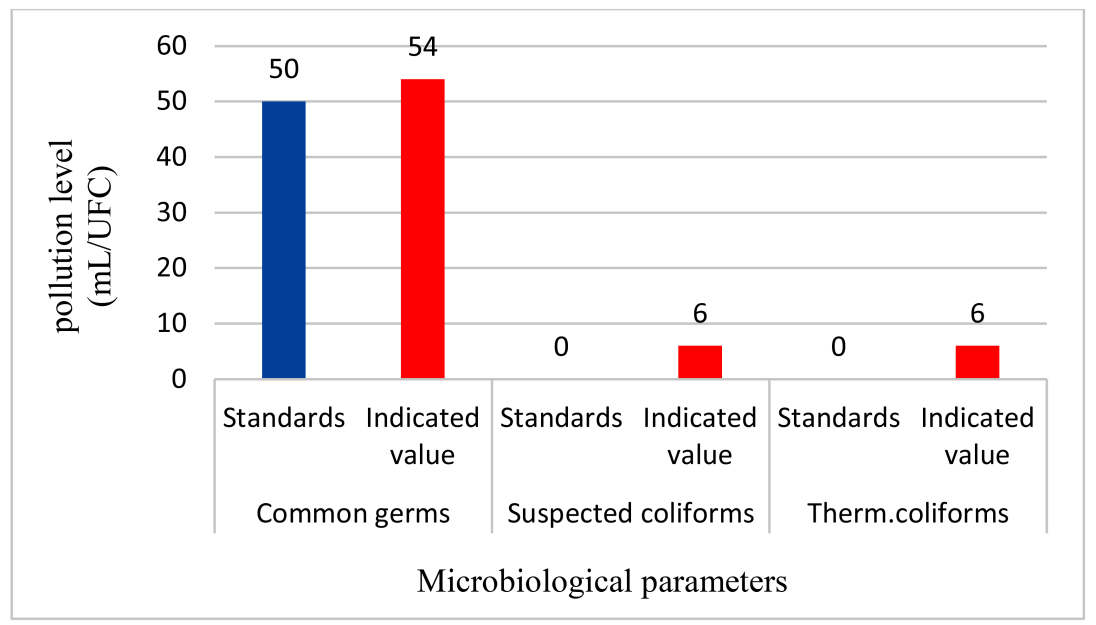

Source: Laboratory work, 2020

Figure 3. Pollution level of the Yobohoué water sample by germs.

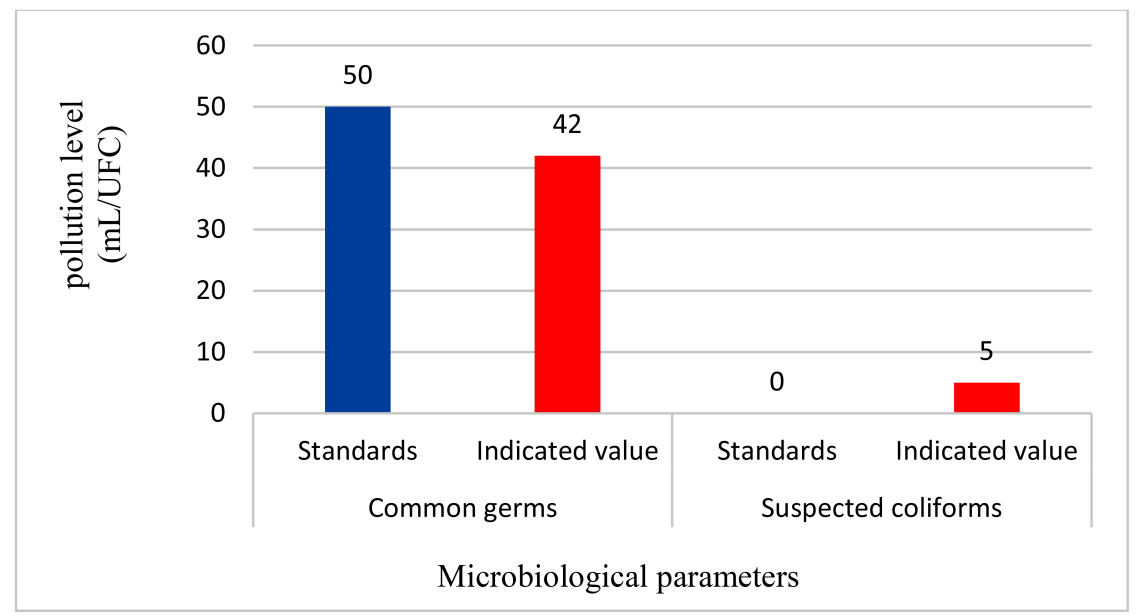

Source: Laboratory work, 2020.

Figure 4. Pollution level of the Tétéhoué water sample by germs. 
hand, the other parameters (thermotolerant coliforms, Escherichia coli) have no value. Analysis of this figure shows that Yobohoués drinking water source does not meet Beninese and WHO standards for the microbiological quality of drinking water.

\subsubsection{SONEB Water}

Figure 5 shows the level of pollution of the SONEB water sample by germs.

Figure 5 indicates that the water sample from the SONEB in the area has a pollution level of $12 \mathrm{~mL} / \mathrm{CFU}$ from common germs. This value is below the standard for the quality of drinking water allowed. On the other hand, the other parameters (Presumed Coliforms, Thermotolerant Coliforms, Escherichia coli) have no value. Analysis of this figure shows that SONEB's drinking water source meets Beninese and WHO standards for the microbiological quality of drinking water.

\section{Discussion}

The results of the physico-chemical analysis presented in this study can be considered admissible and do not present any health impact although the temperature, the hydrogen potential and the ammonium level are high compared to the recommended standard. These values are similar to those of the study of the physico-chemical and bacteriological quality of groundwater from the plio- quaternary water table in the region of Meknes (Morocco) [16]. These results are also comparable with those obtained from the study of the physico-chemical quality of drinking water in Cotonou and Dassa-zoumè [12] [17]. The temperature values in this study are between $28^{\circ} \mathrm{C}$ and $32^{\circ} \mathrm{C}$ and the hydrogen potential $(\mathrm{pH})$ of the water analyzed is acidic with values between 5.4 and 6.8. The temperature content of the four samples in our study did not vary greatly from one water point to another, an average value of $30.15^{\circ} \mathrm{C}$. These results are consistent

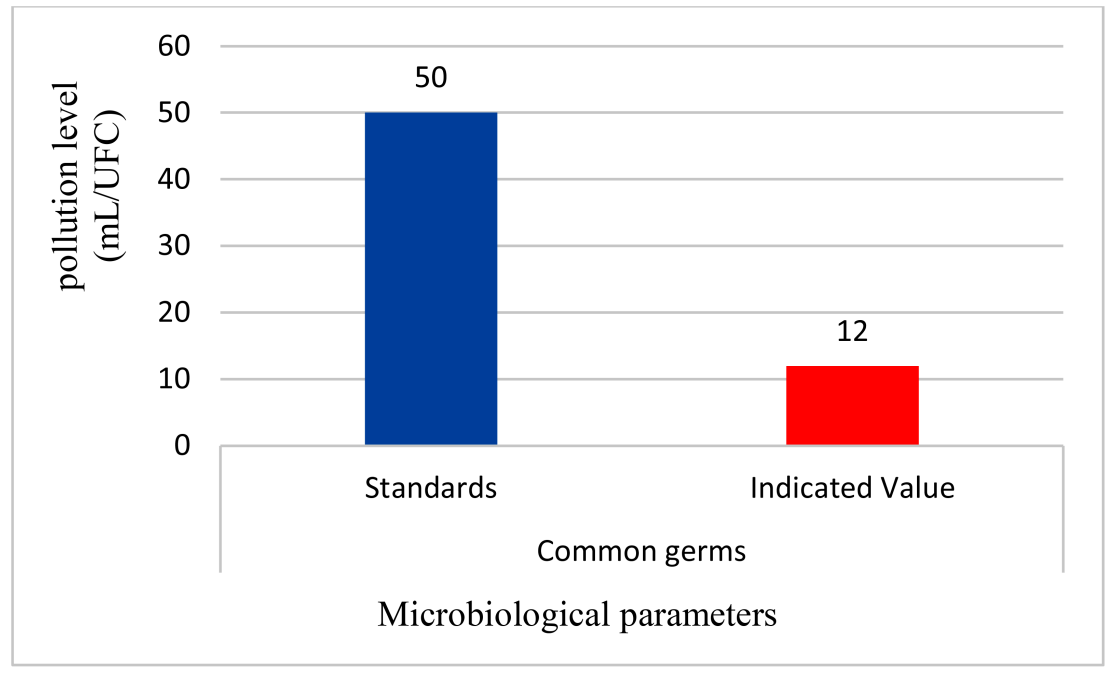

Source: Laboratory work, 2020.

Figure 5. Pollution level of the SONEB water sample by germs. 
with those obtained on the study of the physico-chemical characterization of the feed water from the city of Tijikja in Mauritania between $25.6^{\circ} \mathrm{C}$ and $32.2^{\circ} \mathrm{C}$ [18]. Water with a temperature above $25^{\circ} \mathrm{C}$ constitutes a favorable environment for the development of microorganisms and therefore for water pollution [19]. On the other hand, a low $\mathrm{pH}$ value compared to the standard can present a problem of solubilization of various toxic metals (lead, cadmium, mercury; etc.). The $\mathrm{pH}$ value presented in this study is similar to those obtained from the study of the physico-chemical and microbiological pollution of well water in the $\mathrm{Mu}$ nicipality of Abomey-Calavi in Benin in 2009 [20]. These results are contrary to those obtained in Bingerville on the physico-chemical and bacteriological characterization of groundwater where the ammonium levels are observed in the village of Koffikro with peaks of $3.9 \mathrm{mg} / 1$ [21]. These results are consistent with those obtained in Burkina-Fasso in 2015 on the study of physicochemical characterizations of groundwater in the locality of Yamtenga [22]. Microbiological quality is an essential health concern. The results showed that the microbiological quality of the water samples is relatively satisfactory. Of the four water sources, only two are of good quality. The Yobohoué and Tétéhoué borehole water sample subjected to microbiological analyzes showed high levels of pathologies. The indicator germs are respectively banal germs with a pollution level of $54 / \mathrm{mL}$ of CFU and $42 / \mathrm{mL}$ of CFU; the Presumed Coliforms $6 / 100 \mathrm{~mL}$ and $5 / 100 \mathrm{~mL}$; Thermotolerant coliforms $6 / 100 \mathrm{~mL}$ and $0 / 100 \mathrm{~mL}$. These values do not comply with WHO and Beninese drinking water quality standards [23]. These values are similar to those of the study of the quality of drinking water in the commune of Lalo in southern Benin [24] [25]. The results of this study showed that the microbiological quality of the water samples from artesian wells and AEVs is satisfactory. On the other hand, the microbiological quality of the water from the borehole in the village of Adjaighonou is poor (fecal coliforms: $27 / 100 \mathrm{~mL}$, Total coliforms: 737/100mL, S. aureus: $>150 / 100 \mathrm{~mL}$, Clostridium perfringens: $1 / 20 \mathrm{~mL}$ ). The levels of microbiological parameters observed at the borehole level greatly exceed WHO guidelines and Beninese standards [24] [26]. These results are also similar to the results of the study carried out on drinking water and water-borne diseases in the municipality of Lokossa [19] [17]. This study shows an increasing contamination of the water of the Ablodé-Ahouassa well from the source to the storage where there are maximum values $(3170 / 100 \mathrm{ml}$ for total coliforms, $2675 / 100 \mathrm{ml}$ for fecal coliforms and $2400 / 100 \mathrm{ml}$ for faecal streptococci) [19] [27]. The consumption of such water poses serious risks to the human body. The health impacts of this phenomenon are the high prevalence of diarrhea and intestinal parasitosis in children under 5, pregnant women and elderly people [28] [29]. National coverage of improved water sources in Benin is $78 \%$ and $72 \%$ in rural areas [30]. Despite this improved water source coverage, people still consume poor microbiological quality water at home. However, samples of drinking water from Yobohoué and Tétéhoué subjected to microbiological analyzes do not comply with drinking water quality standards [23] [31]. On the other hand, the sample from 
Ahomey village and the witness (SONEB) comply with the standards provided for in the decree [18]. The high rate of germs [32] in the various boreholes could be explained by the poor protection of these boreholes.

\section{Conclusion}

The results collected during the month of December 2020 made it possible to draw up a description of the physicochemical and microbiological quality of the borehole water for domestic use of the populations of the village of Ahomey. From a physico-chemical analysis point of view, the results obtained can be considered admissible and present no danger for consumption with regard to Beninese standards for the quality of drinking water. In view of the results of the microbiological analysis, the water samples from Yobohoué and Tétéhoué do not meet Beninese standards for the quality of drinking water. These samples show high levels of common organisms, presumed coliforms and thermotolerant coliforms. The latter undoubtedly constitute a threat to the health of the population. To avoid the possibility of any health risk, the authorities must take appropriate measures to preserve the health of the population.

\section{Conflicts of Interest}

The authors declare no conflicts of interest regarding the publication of this paper.

\section{References}

[1] pS-Eau (2012) Access to Drinking Water Countries: 18 Questions for Services. 1st Edition, Paris, p. 52.

[2] pS-Eau (Programme Solidarité-Eau) (2016) Water and Sanitation Services in the Sustainable Development Goals. pS-Eau, Paris, 39.

[3] Coalition-Eau (2019) WHO/UNICEF Report. The UN Publishes New Global Statistics on Home Access for Populations, to Drinking Water, Sanitation and Hygiene. WHO/UNICEF, Geneva, 4.

[4] Solidarity International (2015) Leaflet-Teachers: Drinking Water Our Fight. Paris, p. 4.

[5] Pazou, E.Y.A., Azocli, D., Hinson, A.V., Assogba, B., Avoce, H. and Hozanhekpon, E. (2018) Study of the Quality of Water Consumed in the Commune of Adjohoun in Benin. International Journal of Biological and Chemical Sciences, 12, 1920-1930. https://doi.org/10.4314/ijbcs.v12i4.32

[6] Lakshmi, K. (2012) Chemometric Assessment of Surface Water Quality in Vaigai River, South India. International Journal of Current Research, 4, 71-74.

[7] World Health Organization (2004) Guidelines for Drinking-Water Quality. 3rd Edition, World Health Organization, Geneva.

[8] Barometer-2019, Solidarity-International (2019) Water, Hygiene and Sanitation. Solidarity-International, Clichy, 23 p.

[9] Bhateria, R. and Jain, D. (2016) Water Quality Assessment of Lake Water: A Review. Sustainable Water Resources Management, 2, 161-173.

https://doi.org/10.1007/s40899-015-0014-7 
[10] Barometer-2017, Solidarity International (2017) Access to Sanitation: the Construction of a Latrine. Solidarity-International, Clichy, 4 p.

[11] Water Coalition (2020) Water Sector, Sanitation and Hygiene, Key Figures. The Movement of French NGOs Committed to Access to Water and Sanitation for All. Water Coalition, Paris, 15 p.

[12] Gbohaida, V., et al. (2016) Study of the Physico-Chemical Quality of Drinking Water in Two Localities in Benin: Cotonou and Dassa-Zoumè. International Journal of Biological and Chemical Sciences, 10, 422-434.

https://doi.org/10.4314/ijbcs.v10i1.32

[13] Tyagi, S., Sharma, B., Singh, P. and Dobhal, R. (2020) Water Quality Assessment in Terms of Water Quality Index. American Journal of Water Resources, 1, 34-38. https://doi.org/10.12691/ajwr-1-3-3

[14] Ali, E.N., Muyibi, S.A., Salleh, H.M., Alam, M.Z. and Salleh, M.R.M. (2010) Production of Natural Coagulant from Moringa Oleifera Seed for Application in Treatment of Low Turbidity Water. Journal of Water Resource and Protection, 2, 259-266. https://doi.org/10.4236/jwarp.2010.23030

[15] Nangbe, F. (2006) Monograph of the Commune of Dogbo. Africa Council, 42.

[16] Belghiti, M.L., Chahlaoui, A., Bengoumi, D., EL Moustaine, R. (2013) Study of the Physico-Chemical and Bacteriological Quality of Groundwater from the Plio-Quaternary Water Table in the Region of Meknes (Morocco). Larhyss Journal, No. 14, 21-36.

[17] Bain, R., Johnston, R., Khan, S., Hancioglu, A. and Slaymaker, T. (2021) Monitoring Drinking Water Quality in Nationally Representative Household Surveys in Lowand Middle-Income Countries: Cross-Sectional Analysis of 27 Multiple Indicator Cluster Surveys 2014-2020. Environmental Health Perspectives, 129, Article ID: 097010. https://doi.org/10.1289/EHP8459

[18] Ould Cheikh, M., El Kacemi, K. and Idrissi, L. (2012) Physico-Chemical Characterization of the Water Supply of the City of Tijikja (Mauritania). International Journal of Biological and Chemical Sciences, 5, 2133-2139.

https://doi.org/10.4314/ijbcs.v5i5.33

[19] Dimitri Miriac, A.S., Noukpo, A. and Christophe, H.S. (2020) Consumption Water and Waterborne Diseases in the Municipality of Lokossa in the South-West of the Republic of Benin (West Africa). European Scientific Journal, 16, 393-417. https://doi.org/10.19044/esj.2020.v16n15p393

[20] Degbey, C., Makoutode, M., Ouendo, E. and De Brouwer, C. (2011) Physico-Chemical and Microbiological Pollution of Well Water in the Municipality of Abomey-Calavi in Benin in 2009. International Journal of Biological and Chemical Sciences, 4, 2257-5571. https://doi.org/10.4314/ijbcs.v4i6.64910

[21] Kanohin, F., Otchoumou, E., Yapo, O.B., Dibi, B. and Bonny, A.C. (2018) Physicochemical and Bacteriological Characterization of Bingerville Groundwater. International Journal of Biological and Chemical Sciences, 11, 2495-2509. https://doi.org/10.4314/ijbcs.v11i5.43

[22] Ayouba Mahamane, A. and Guel, B. (2015) Physico-Chemical Characterizations of Groundwater in the Locality of Yamtenga (Burkina Faso). International Journal of Biological and Chemical Sciences, 9, 517-533. https://doi.org/10.4314/ijbcs.v9i1.44

[23] Ministry of Health (2001) Standards No. 2001-094 of February 20, 2001 on the Quality of Drinking Water in the Republic of Benin. Ministry of Health, Porto-Novo.

[24] Amoukpo, H., Toffa, D., Boni, G., Salou Bachirou, Z., Wari, M., Fandohan, I., et al. (2019) Improving the Microbiological Quality of Drinking Water at Home in the Communes of Lalo and Zè (Benin). Environnement, Risques \& Santé, 17, 611-618. 
[25] Parparov, A. (2010) Water Quality Assessment, Trophic Classification and Water Resources Management. Journal of Water Resource and Protection, 2, 907-915. https://doi.org/10.4236/jwarp.2010.210108

[26] Adidjatou, O., Alassane, M., Theodor, D. and Howélé, O. (2016) Study of the Quality of Drinking Water in the Locality of N'Zianouan s/p of Tiassalé and the Precarious Districts of Three Communes of the District from Abidjan (Koumassi, Treichville, Attécoubé). Journal of Applied Biosciences, 8 p.

[27] Brou, D., et al. (2013) Assessment of the Vulnerability to Pollution of Aquifers of alterite Formations Using the DRASTIC and SYNTACS Methods: Case of the Town of M'bahiakro, Center of Côte d'Ivoire. International Journal of Innovation and Applied Studies, 2, 464-476.

[28] Wang, X., Younan, D., Petkus, A.J., Beavers, D.P., Espeland, M.A., Chui, H.C., et al. (2021) Ambient Air Pollution and Long-Term Trajectories of Episodic Memory Decline among Older Women in the WHIMS-ECHO Cohort. Environmental Health Perspectives, 129, Article ID: 097009. https://doi.org/10.1289/EHP7668

[29] Lind, L., Araujo, J.A., Barchowsky, A., Belcher, S., Berridge, B.R., Chiamvimonvat, N., et al. (2021) Key Characteristics of Cardiovascular Toxicants. Environmental Health Perspectives, 129, Article ID: 095001. https://doi.org/10.1289/EHP9321

[30] WHO/UNICEF Joint Water Supply and Sanitation Monitoring Program, World Health Organization, and UNICEF (2015) Progress on Sanitation and Drinking Water.

[31] Saint-Laurent, D., Hähni, M. and Barrett, S.A. (2010) Analysis of Contaminated Sediments from the Southwestern Portion of Lac Saint-Pierre (Quebec, Canada). Journal of Water Science, 23, 119-131. https://doi.org/10.7202/039904ar

[32] Patoine, M. (2012) Influence of Animal Density on the Concentration of Fecal Coliforms in the Rivers of Southern Quebec, Canada. Journal of Water Science, 24, 421-435. https://doi.org/10.7202/1007628ar 